(chairman), Mr. J. C. Bridge, Prof. A. J. Clark, Prof. A. G. Green, Prof. J. A. Gunn, Prof. E. H. Kettle, Dr. H. B. Morgan, Mr. J. Davidson Pratt, Mr. D. R. Wilson and Sir David Munro (secretary).

\section{International Office for the Protection of Nature}

THE' Dutch and French Governments have now officially recognised the International Office for the Protection of Nature at Brussels and have appointed the following delegates to be their representatives on the general council of the Office : Netherlands and Dutch East Indies: Dr. P. G. van Tienhoven, president of the Society for Nature Protection in Netherlands; Dr. W. A. J. M. van Waterschoot van der Gracht, chief engineer of mines; Prof. L. Ph. le Cosquino de Bussy, director of the Colonial Institute, Amsterdam; Dr. J. C. Koningsberger, former Minister of Colonies. France and Colonies : M. M. Bolle, conservator of forests, Ministry of Agriculture, Paris ; Prof. A. Gruvel, general secretary of the National Committee for the Preservation of Fauna and Flora in the Colonies; M. Raoul de Clermont, president of the Section for Nature Protection of the Socióté Nationale d'Acclimatation de France.

\section{Speleological Research in Great Britain}

AT the meeting of representatives of associations interested in the exploration of caves from Yorkshire and Lancashire, Derbyshire and Staffordshire, Somerset and Devon, South Wales and Ireland (see Nature, July 20, p. 98) held at Derby on July 27, over which Prof. L. S. Palmer (Hull) presided, it was resolved to form a British Speleological Association to serve as a clearing house for the co-ordination of the hydrological, geological, geographical, archæological and biological aspects of cave exploration, and for the dissemination of information relating thereto. In the course of the discussion which preceded the carrying of the resolution, stress was laid on the damage done by promiscuous and uninstructed digging in caves, Mr. A. L. Armstrong (Warrington) in particular urging, the need for training before any attempt is made to carry on the work of excavation. The meeting also adopted a proposal that Sir Arthur Keith should be invited to become the first president of the Association.

\section{Awards of the Royal College of Physicians}

AT a meeting of the Royal College of Physicians of London held on July 25, the president announced the award of the Baly medal to Dr. F. H. A. Marshall, as a pioneer in the experimental investigation of sexual physiology and the relation of hormones to it ; and the award of the Bisset Hawkins medal to Sir George Newman, for his distinguished services to public health, and more particularly for the leading part played by him in the institution of social medical services. Leverhulme scholarships were awarded to Dr. R. L. Noble and Dr. C. C. Ungley; and a grant from the same fund to Dr. Janet Vaughan to continue the work on which she was engaged before relinquishing her scholarship. Dr. E. G. L. Bywaters and Dr. L. C. Bousfield were re-appointed for six months as Mackenzie Mackinnon scholars. The Murchison scholarship was awarded (by the University of Edinburgh) to W. M. Wilson.

\section{Announcements}

THE twelfth International Congress of Zoology will be held at Lisbon in September under the presidency of Prof. Arthur Ricardo Jorge, Jr. Further information can be obtained from the general secretary, Congrès international de Zoologie, Faculté des Sciences, Lisbon.

A CONFERENCE on academic freedom will be held in the University Museum, Oxford, on August 14-15. It will be divided into three sessions, namely: academic and professional freedom; international professional relief; and the utilisation of science. Among the speakers will be Bertrand Russell, G. D. H. Cole, Prof. N. Bentwich, Miss J. Thomas, Prof. H. Levy, L. J. Hodgson. Further information can be obtained from C. R. Morris, Balliol College, Oxford.

THE tenth and eleventh reports of the Committee on Contact Catalysis, Division of Chemistry and Chemical Technology, have been issued together by the National Research Council, Washington. They deal with general aspects of catalysis, activated adsorption, the nature of chemical binding, interchange of energy in molecular collisions, chain reactions and some technical applications of catalysts.

Applications are invited for the following appointments, on on before the dates mentioned :

A temporary assistant lecturer in applied mathematics in the University of Liverpool-Registrar (Aug. 10).

A biochemist (part-time) for the Pathological Department, Manchester Northern Hospital-The Secretary, J. C. Daniels, 38 Barton Arcade, Manchester (Aug. 10).

A lecturer in botany in the United College, St. Andrews-Secretary and Registrar (Aug. 10).

An assistant (Grade III) and a temporary assistant (Grade II) in the Admiralty Compass Department, Slough-Secretary of the Admiralty (C.E. Branch), London, S.W.1 (Aug. 10).

A veterinary research officer to the Government of Burma - The High Commissioner for India, General Department, India House, Aldwych, London, W.C.2 (Aug. 14).

An assistant lecturer and demonstrator in engineering in University College, Cardiff-The Registrar (Aug. 19).

Two assistant keepers at the Victoria and Albert Museum-Director and Secretary, South Kensington, London, S.W.7, marked "Assistant Keeper" (Aug. 31).

City microbiologist to the Municipal Council, Colombo, Ceylon (candidates to be from the United Kingdom)-Messrs. John Pook and Co., 68 Fenchurch Street, London, E.C.3 (Sept. 30).

A lecturer in geography and mathematics in St. Hild's College, Durham-The Principal. 